\title{
Influence of Employees and Business Size on SME Income
}

\author{
Aman Suyadi*, Siti Nur Azizah, Selamet Eko Budi Santoso \\ Universitas Muhammadiyah Purwokerto \\ Purwokerto, Indonesia \\ *amansuyadi@ump.ac.id, sitinurazizah@ump.ac.id, budi.imm@gmail.com
}

\begin{abstract}
The study's objective is to measure the effect of the number of employees and size of the business on the income of SMEs in the livestock sector and their processed products. The population in this study were all SMEs in the livestock sector and their processing products located in Banyumas district. 46 questionnaires filled by respondents were collected as the technique in this study. The sample used are all SME livestock entrepreneurs and their processing products in Banyumas district. This research used primary data type then were processed with purposive sampling technique which is analyzed using multiple linear regression. Our findings prove that the employees number and the size of the business have no impact on the income of SMEs in the livestock sector and their processing products. The practical implication of this research is as a reference for business actors in making strategic plans for their business development.
\end{abstract}

Keywords-employes, size, income, SMEs

\section{INTRODUCTION}

In this global era, many types of businesses have been developed by the community, one of which is Small and Medium Enterprises (SMEs). This business is a unique business unit which is organized by the community in small or medium scale. This operational in the form of private businesses, business groups, or the family business that is still on a certain scale (mostly small or medium). SMEs have essential role in economic development of the country strategically. This role is not only regarding its contribution on national economic growth SMEs, but also absorb productive labor in wide numbers [1]. SMEs are not only a business but are an economic driver of a country because the SME sector has a significant contribution to employment, which absorbs more than $99.45 \%$ of the society as the worker and contributes to GDP of approximately $30 \%$ [2].

Seeing the urgency of SMEs for the country's economy, the state must defend the SME sector, especially in relation to the sector's income. With a large income, any company sector including SMEs will have more power in managing its business so that the business continues and develops over time. SMEs have unique characteristics that are slightly different from companies in general regarding business management. In managing a business, an SME is faced with a choice for business continuity in the future. SME entrepreneurs can freely regulate the use of business capital for their business development, some SME entrepreneurs develop their business through adding assets, some choose to add employees to increase their productivity.

One of the interesting SME to be examined is livestock sector. The livestock sector is a vital sector in the process of meeting food needs for the community. Animal husbandry products are a source of animal protein which is needed by the body to maintain nutritional balance and increase immunity to ward off various diseases. In addition, this sector also absorbs a lot of workforce, both directly and indirectly. In the formation of Indonesia's Gross Domestic Product (GDP), the livestock sub-sector contributed 1.57 percent to the 2017 National GDP [3]. Based on data from the employment survey nationally on the Indonesian Central Statistics Agency (BPS) stated that on August 2017, there are 3.84 million employment who work in the livestock sector. It can be calculated that the livestock sector contributes $3.17 \%$ to the national employment [4].

In Indonesia, livestock products are a basic need that has not been fulfilled independently. Until now, the price of livestock products cannot be reached by the community as a whole because it is relatively expensive. The middle and lower class people often find it difficult to buy and enjoy because of high product prices and their income is not easy to reach. The low demand for livestock has made the number of breeders even less likely to stop. 


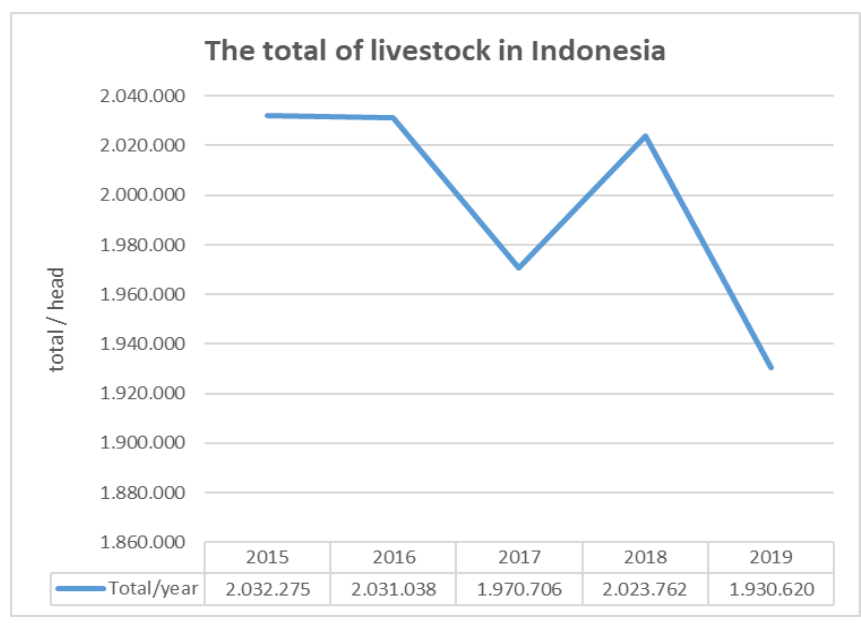

Fig. 1. The total of livestock in Indonesia.

Based on data from the Central Statistics Agency (BPS) (figure 1), it shows a significant decrease in the number of livestock in recent years, this is of particular concern because this phenomenon not only reduces the production of livestock products but also affects labor absorption and the development of entrepreneurs in the livestock sector. The number of livestock in 2017 decreased by 60,332 heads or $3 \%$ from a total of 2,032,275 heads in 2016. In addition, in 2019 there was an even greater decline of around $4.6 \%$ or a total of 93,142 heads from 2,023762 heads in 2018.

According to Kusuma [5] company size affects company profits. Company size was analyzed as total number of employees and assets owned [6]. Amelia and Hernawati [7] also state that the proxies commonly used to measure company size are total assets and number of employees. Dhawan [8] states that assets are company assets as a measure of the level or level of the company. So that the greater the company's assets, the greater the value or size of the company [9]. Putra and Lestari [10] revealed that company size partially effect on company income positively significant. However, Putra and Badjra [11] revealed that company size negatively effects on company revenue. Based on the phenomena and research gaps that occur, it is necessary to carry out further research related to the influence of the number of employees and company assets on income of SMEs engaged in the livestock sector.

\section{LITERATURE REVIEW}

This research uses the theory of Pecking Order which was firstly demonstrated by Donaldson around the year 1984 [12] which was later refined by Myers and Majluf [13]. The theory of pecking order states that companies tend to seek sources of funding with minimal risk. The risk of decreasing company value. This theory originates from the presence of asymmetric information because managers have a better understanding of the prospects, risks and value of the companies which is controlled by them than investors as the outside. Asymmetric information can influence the choice between internal and external financing and regarding debt or equity issues.
Information asymmetry supports debt-to-equity issues because debt issues represent the board's belief that an investment is profitable and that the current share price is undervalued (if stock prices are overvalued, equity issues are preferred). Equity problems indicate a low level of trust in the board and that they feel the share price is overvalued. These equity problems can lead to lower share prices. However, this does not apply to high-tech industries where equity issues are preferred because of the high cost of debt problems due to high intangible assets [14].

In SMEs, the pecking order theory (pecking order model) presumes that financial costs increase with asymmetric information. Financing comes from three sources, which are internal funds, debt and new equity. the order of priority of companies regarding sources of financing is internal financing. internal financing is a fund that can be used by business managers. The second priority is debt, which is external funds obtained by providing guarantees which will be exchanged in the future. the last priority is to increase equity as a last resort to meet business needs. In a priority scale, it describes that internal financing will be used first as an effort to increase business. Furthermore, when internal funds have reached the limit point and are exhausted, the entrepreneur will apply for a debt or loan. Under certain conditions, business actors cannot apply for loans, so SMEs will liquidate their equity to get fresh funds as business operating capital.

In this study, pecking order theory plays a role as one of the efforts of business actors to improve their business by adding assets both tangible and intangible. Tangible assets are assets owned by the entrepreneur to support business operations, while intangible assets are in the form of employee ownership to support the business.

\section{A. Small and Medium-Sized Enterprises (SMEs)}

SMEs are businesses whose number of business actors or personnel is below a certain limit. This business is a pioneer business that was first implemented and developed so that within a certain point in time it can develop into an increasingly large scale business. An increasing business scale will be followed by an increase in the scope of business and the number of employees needed so that this SME has the potential to increase the level of a country's economy. The term "SME" is not only used in Indonesia, but the term is also conducted by international organizations for instance the World Bank, European Union, United Nations and the World Trade Organization (WTO).

The current phenomenon is that the number of SMEs exceeds the number of wide companies by a large margin and also employs more workers. As illustration, the number of SMEs in Australia is $98 \%$ of all businesses there. This ratio represents one-third of total GDP and employs 4.7 million employees. Of the other countries for example in Chile 2014, $98.5 \%$ of the existing companies id that country are classified as SMEs [15]. In addition, the total workforce in Tunisia accounts for $28 \%$ of total non-agricultural employment and companies with less than 100 employees account for about 
$62 \%$ of total jobs available in the country [16]. In developing countries, small and informal enterprises have a greater scope or percentage than in developing countries. SMEs are also responsible for encouraging innovation and competition in many sectors of the economy. However, although SMEs create more new job field than large firms, most of the layoffs occurred for SMEs more than large firms [17].

SMEs have an important role in the economic and social sectors, especially in relation to jobs. Based on the size of the business, the operational activities and decision-making processes of SMEs are strongly influenced by the Chief Executive Officer (CEO). CEOs of SMEs are often the founders or owners of the SMEs themselves. So that the separation of CEO duties in the SME sector will be difficult to analyze and compare with the duties of CEOs in large companies. CEOs in SMEs need to allocate strategically their time, energy and assets to direct SMEs. In addition, CEOs in the SME sector are required to have the ability of strategists, champions and leaders to develop SMEs or the main reason for business failure. Meanwhile, at the employee level, a CEO is required to have a role of trust and interpersonal knowledge in a number of small and medium enterprises [18]. So it can be concluded that knowledge positively affects the number of SMEs, which in turn positively affects interpersonal trust. It should be noted that the empirical results show that interpersonal belief does not affect the number of SMEs. Therefore, although knowledge development can strengthen SMEs, trust will expand in society when the number of SMEs increases. In Indonesia, the government defines SMEs based on the assets and income according to UU no. 20/2008 [19]:

TABLE I. SMES IN INDONESIA

\begin{tabular}{|l|l|l|}
\hline Type of Business & Assets owned (Rupiah) & $\begin{array}{c}\text { Revenue received } \\
\text { (Rupiah) }\end{array}$ \\
\hline Micro & $<50,000,000$ & $<300,000,000$ \\
\hline Small & $<500,000,000$ & $<2,500,000,000$ \\
\hline Medium & $<10,000,000,000$ & $<50,000,000,000$ \\
\hline
\end{tabular}

\section{B. Employees}

Residents who include into the working age category. According to UU no. 13 of 2003 Chapter I article 1 paragraph 2 , it is written that labor is any person who is able to do work in order to produce goods or services either to meet their own needs or for the community. Specifically, the population of a country can be divided into two groups, namely the labor force and non-work force. The population is classified as the labor force if the population has entered the working age. The working age limit in Indonesia is 15 - 64 years. According to this definition, every citizen who is able to work is called labor. There are many opinions regarding the age of these workers, some express the opinion that the workforce is citizens who are over 17 years old, some are over 20 years old, some even say over 7 years old because street children are included in the labor force.
Employees are human potentials who have a role as a driving force for the organization in realizing its existence or potential. Employees in a company are assets and function as non-material capital in a business organization that can be realized into real potential both physically and non-physically in realizing the existence of the organization [20]. Employees are everyone who works by selling their energy (physical and mental) to a company and receiving remuneration in accordance with the agreement [21].

\section{Assets}

Assets are resources owned by an entity or business that have economic value. Assets are anything (tangible or intangible) that can be owned or controlled to produce value when utilized. in addition, assets are resources held by an economic entity and can generate positive economic value. In simple terms, assets are the value of ownership that can be converted into both domestic and foreign currencies (including cash) [22]. These assets must be reported in a company's balance sheet which memorizes the monetary value of assets owned by the company [23]. This recording includes money and other valuable items of individuals or businesses [22].

Assets can be classified into two main asset classes, there are tangible and intangible assets. Tangible assets are grouped into several subclasses, called current assets and fixed assets [24]. Current assets consist of inventory, while fixed assets include buildings and properties. Intangible assets are nonphysical resources and rights that have value for the company because they provide profit value for the company in the market. Intangible assets can take the form of goodwill, copyrights, trademarks, patents, computer programs [25], and financial assets, including receivables, bonds and stocks [24].

\section{Income}

Income is remuneration received by a company or entity for its business. Income that has not been deducted from expenses is called gross income. In addition, income can also be interpreted as consumption and saving opportunities for an entity within a certain period of time. In general, income is expressed in monetary terms or certain currency units [26,27]. In household and individual terms, income is the sum of all wages, salaries, profits, interest payments, rent, and other forms of income received in a certain period of time [25]. In a trading company, gross income can be defined as the sum of all revenue less the cost of goods sold on the goods traded. Meanwhile, net income is all income received minus the cost of goods sold, expenses, depreciation, interest and taxes which are included in all operational and non-operational activities [27].

\section{E. Research Framework and Hypothesis}

Based on several previous studies, the research framework in this study is as follows (figure 2): 


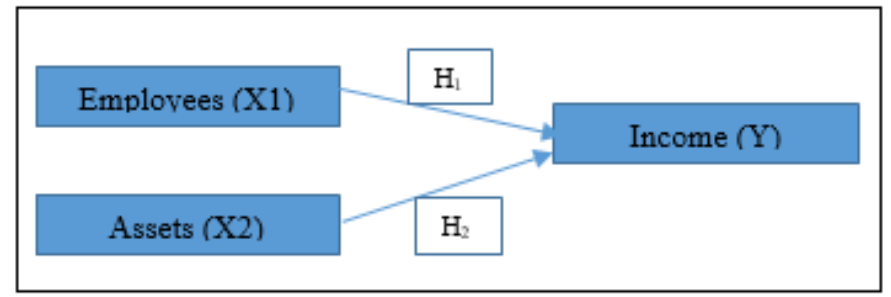

Fig. 2. Research framework.

\section{F. Effect of Employees on Income}

Employees are human resources owned by the company. Employees are company assets that can be used for added value. Good employees can increase the value of company productivity so that it will have an impact on income. Conversely, employees who have poor character have the potential to have a negative impact on the company, both financially and non-financially. According to Malik and Siringoringo [28], the number of employees has a direct and significant effect on the income of SMEs.

The number of employees is the number of people who work at the shop. The number of employees is a factor that supports the company's survival, because business productivity is largely determined by the number of existing employees [29] while according to Handika and Fatimah [30] the number of employees is someone who is able to do work both inside and outside the work relationship for produce goods or services to meet community needs. According to Imron and Wibowo [29], the number of employees is an important factor in production activities and serving buyers, the more the number of employees will increase the quality of service to buyers so that buyers will be satisfied with the services provided and the more customers will increase so that income.

Theoretically based on pecking order theory, internal factor like owner's assets can be classified as first priority to increase business scale in SMEs. Employees are one of intangible assets which are possible to be explored. A large number of employees can support business activities that directly impact the income received by these business activities. Based on this description, the following hypothesis can be formulated:

H1 : The number of employees has a positive effect on the income of SMEs.

\section{G. The Effect of Assets on Income}

Asset or property is one of the important elements that must be paid attention by the management of the company in carrying out its business activities. One of the components of assets is capital. According to Nurhayati [31], capital is a fund needed by a company to meet the company's daily operational needs, such as purchasing raw materials, paying labor wages, paying debts and other payments. Initial capital is an important factor in business activities. The bigger the initial capital, the wider the opportunity to develop the business. Initial capital consists of own capital and non-own capital which is usually a loan. The initial capital is used to finance his day-to-day business activities, such as purchasing merchandise, paying for labor and providing merchandise. Several previous studies on the informal sector indicate a direct relationship between initial capital and income levels.

According to Malik and Siringoringo [28], the capital or set has an effect on operating income. The more capital an entrepreneur has, the more freely it will be used and developed to generate income [9], Meidiana and Marhaeni [32] state that oily assets tend to contribute to material welfare rather than assets that are few. Based on pecking order theory, internal ownership include assets as the owner tangible assets to support the business. Thus, according to the description, the second hypothesis can be formulated as follows:

$\mathrm{H} 2$ : Total assets have a positive effect on the income of SME

\section{Methodology}

This type of research is quantitative research, which is research in the form of numbers or numbers [33]. The population in this study are SMEs entrepreneurs in Banyumas Regency and the sample is focus on livestock sector. The operational definitions of variables and measurement of variables. Income is the turnover received by entrepreneurs in managing a business before deducting various operating costs. Employees are the total workforce owned by SMEs in running their business. Asset is the total assets owned by SME entrepreneurs in managing the business, these assets can be in the form of inventory and operating capital.

This research uses purposive sampling of all SMEs in livestock sectors in Banyumas which is consist of 46 people. Before doing the analysis, it is necessary to first test the classical assumptions to test the quality of the data used in the study. The classic assumption test used in this study is the normality test, multicollinearity test and heteroscedasticity test. After the test is carried out and shows good results, it will be continued with testing using multiple regression analysis.

\section{RESULTS AND DISCUSSION}

Based on the results of research from 46 respondents, namely SME entrepreneurs in the livestock sector in Banyumas district, the results of the descriptive analysis are as follows: Based on the descriptive analysis table, it shows that the employee variable has a mean value that is greater than the standard deviation value, which means that it shows good data distribution. On the contrary, the variable assets and income have a men value that is lower than the standard deviation, which means that the value of the data distribution is not good. 
TABLE II. DESCRIPTIVE STATISTICS

\begin{tabular}{|l|l|l|l|l|l|}
\hline & $\mathbf{N}$ & Minimum & Maximum & \multicolumn{1}{|c|}{ Mean } & \multicolumn{1}{|c|}{ Std. Deviation } \\
\hline Employee & 46 & 4 & 15 & 6.15 & 3.14 \\
\hline Assets & 46 & $2,000,000$ & $350,000,000$ & $58,728,260.87$ & $66,518,079.958$ \\
\hline Income & 46 & $18,000,000$ & $960,000,000$ & $172,875,000.00$ & $182,039,024.739$ \\
\hline $\begin{array}{l}\text { Valid N } \\
\text { (listwise) }\end{array}$ & 46 & & & & \\
\hline
\end{tabular}

The results of the normality test show a sig value of $0.093>$ 0.05 , which means that the research data is normally distributed based on the results of the normality test with Kolmogorov Smirnov.

TABLE III. ONE-SAMPLE KOLMOGOROV-SMIRNOV TEST

\begin{tabular}{|l|l|l|}
\hline \multicolumn{2}{|l|}{} & \multicolumn{1}{|c|}{ Standardized Residual } \\
\hline $\mathrm{N}$ & Mean & 46 \\
\hline Normal Parameters $^{\mathrm{a}}$ & Std. Deviation & .9000000 \\
\hline \multirow{2}{*}{ Most Extreme Differences } & Absolute & .183 \\
\cline { 2 - 3 } & Positive & .183 \\
\cline { 2 - 3 } & Negative & -.115 \\
\hline Kolmogorov-Smirnov Z & 1.238 \\
\hline Asymp. Sig. (2-tailed) & .093 \\
\hline
\end{tabular}

The results of the multicollinearity test data show the value of VIF $<10$, it means that there are no multicollinearity between independent variables or employee and asset variables are not related to each other.

TABLE IV. COEFFICIENTS ${ }^{\mathrm{A}}$

\begin{tabular}{|l|l|l|l|l|l|}
\hline \multicolumn{2}{|c|}{ Model } & \multicolumn{2}{c|}{} & \multicolumn{2}{c|}{ Collinearity Statistics } \\
\cline { 5 - 6 } & & t & \multicolumn{1}{c|}{ Sig. } & Tolerance & \multicolumn{1}{c|}{ VIF } \\
\hline \multirow{2}{*}{1} & (Constant) & 1.562 & .126 & & \\
\cline { 2 - 6 } & Employees & 1.303 & .200 & 0.997 & 1.003 \\
\cline { 2 - 6 } & Assets & .043 & .966 & 0.997 & 1.003 \\
\hline
\end{tabular}

a. Dependent Variable: Income

The results of the Heteroscedasticity test data with the Park method show that all independent variables have a sig value > 0.05 , it means that there is no heteroscedasticity problem between the independent variables used in this study.
TABLE V. COEFFICIENTS ${ }^{\mathrm{A}}$

\begin{tabular}{|c|c|c|c|c|c|c|}
\hline \multirow{2}{*}{\multicolumn{2}{|c|}{ Model }} & \multicolumn{2}{|c|}{$\begin{array}{c}\text { Unstandardized } \\
\text { Coefficients }\end{array}$} & \multirow{2}{*}{\begin{tabular}{|c|}
$\begin{array}{c}\text { Standardized } \\
\text { Coefficients }\end{array}$ \\
Beta \\
\end{tabular}} & \multirow[b]{2}{*}{$\mathbf{t}$} & \multirow[b]{2}{*}{ Sig. } \\
\hline & & $B$ & $\begin{array}{l}\text { Std. } \\
\text { Error }\end{array}$ & & & \\
\hline \multirow[t]{3}{*}{1} & (Constant) & 28.255 & 4.220 & & 6.695 & 0.000 \\
\hline & Assets & 0.257 & 0.216 & 0.169 & 1.193 & 0.240 \\
\hline & Employees & 2.344 & 0.695 & 0.478 & 3.371 & 0.062 \\
\hline
\end{tabular}

a. Dependent Variable: Incom

Based on the results of multiple regression tests, it shows that the $\mathrm{R}$ square value is 0.037 , which means that the variants of Employees and Assets can affect income by 3.7\%.

TABLE VI. MODEL SUMMARY

\begin{tabular}{|l|c|l|l|l|}
\hline Model & $\mathbf{R}$ & R Square & Adjusted R Square & Std. Error of the Estimate \\
\hline 1 & $.195^{\mathrm{a}}$ & 0.038 & 0.037 & $1.827 \mathrm{E} 8$ \\
\hline
\end{tabular}

Based on the results of the analysis test, the regression equation can be concluded as follows:

$\mathrm{Y}=102,269,713.775+11,307,572.355$ Employ +0.018 Assets $+\mathrm{e}$

The multiple regression equation shows that the constant value is high so that the effect of the independent variable is small.

TABLE VII. COEFFICIENTS ${ }^{\mathrm{A}}$

\begin{tabular}{|c|c|c|c|c|c|c|}
\hline \multirow{2}{*}{\multicolumn{2}{|c|}{ Model }} & \multicolumn{2}{|c|}{$\begin{array}{c}\text { Unstandardized } \\
\text { Coefficients }\end{array}$} & \multirow{2}{*}{$\begin{array}{c}\begin{array}{c}\text { Standardized } \\
\text { Coefficients }\end{array} \\
\text { Beta }\end{array}$} & \multirow[b]{2}{*}{$\mathbf{t}$} & \multirow[b]{2}{*}{ Sig. } \\
\hline & & $\boldsymbol{B}$ & Std. Error & & & \\
\hline 1 & (Constant) & $102,269,713$ & $65,489,125$ & & 1.562 & .126 \\
\hline & Employees & $11,307,572$ & $8,680,488$ & 0.195 & 1.303 & 0.200 \\
\hline & Assets & 0.018 & 0.410 & 0.006 & 0.043 & 0.966 \\
\hline
\end{tabular}

Based on the analysis table, it shows that the p-value of the employee variable is $0.200>0.05$, which means that $\mathrm{H}_{1}$ is rejected or not proven. This indicates that based on research data, the number of employees owned by SME entrepreneurs does not affect the level of income earned. For the SME sector, which has a large or small number of employees, it does not have any impact on the income received by the livestock sector UKM entrepreneurs in Banyumas. The results of this study are because most of the research sample chooses to limit the number of employees, so that the average employee ownership is sufficient (low).

The results of this study are different from the pecking order theory in previous studies because the hypothesis testing in this study is on SME, while the previous research testing 
was carried out on large companies that have clear roles and separation of responsibilities. In practice, SME is different from other large companies because of its unique characteristics such as roles, duties and responsibilities, mostly in the CEO or owner who is usually the same person. this affects various policies such as the decision to increase the number of employees or not. Thus, a decrease or increase in the number of employees will not have any impact on SME income because SMEs themselves still rely heavily on the role of business owners rather than delegating responsibilities to employees. The results of this study inline with the others research [34-36].

Based on the results of the analysis, it shows that the Assets variable has a p-value of $0.062>0.05$ so that $\mathrm{H}_{2}$ is rejected. This shows that assets have no effect on income, which means that the higher or lower the number of assets owned has no impact on the income of SMEs. This different with the Pecking Order theory which believes that an increase in assets can support an increase in business (income). Based on research data, some SMEs are interested in increasing their assets through additional capital from outside parties such as banking. However, some SMEs avoid this because they are worried that they will not be able to fulfill their payment obligations when their income is uncertain. This makes most of the SMEs very careful before adding their business assets (personal). For entrepreneurs who already feel confident that their business will grow rapidly when there are additional assets, they will tend to make any effort to increase their assets which will have an impact on increasing income. However, for entrepreneurs who still doubt the consistency of their business, even though they have many assets, they will not fully use them for overall business development. So the level of assets cannot affect income because the tendency to add assets depends on the personality of the business owner. The results of this study support the others research results [34-36]

\section{CONCLUSION}

Based on the research results, it can be concluded that the income factor of SMEs cannot be influenced by internal factors such as employees and assets owned by the business. This means that the size of the number of employees and assets owned by business actors cannot affect the level of business income of SMEs in the livestock sector in Banyumas Regency.

\section{REFERENCES}

[1] S.N. Azizah, "Analysis of Factors Affecting the Implementation of Computer-based Accounting Information System on Small and Medium Enterprises.” Jurnal Ekonomi \& Studi Pembangunan, vol. 18, no. 2, pp. 111-115, 2017.

[2] D.A.I.Y.M. Dewi and G.M. Sudiartha, "Pengaruh Profitabilitas, Ukuran Perusahaan, Dan Pertumbuhan Aset Terhadap Struktur Modal Dan Nilai Perusahaan.” E-Jurnal Manajemen Universitas Udayana, vol. 6, no. 4, 2017.

[3] S. Deny, "Peternakan Jadi Sektor Penting Bagi Pertumbuhan Ekonomi Pedesaan." 2017, [Online]. https://www.merdeka.com/uang/peternakan-jadi-sektor-penting-bagipertumbuhan-ekonomi-pedesaan.html.

[4] G. Hartomo, "Peternakan jadi kunci penting perekonomian Indonesia. Ini Penjelasannya." 2018, [Online]. Retrieved from .https://economy.okezone.com/read/2018/07/04/320/1917701/peternaka n-jadi-kunci-penting-perekonomian-indonesia-ini penjelasannya.

[5] H. Kusuma, "Size Perusahaan dan Profitabilitas: Kajian Empiris terhadap Perusahaan Manufaktur yang Terdaftar di Bursa Efek Jakarta." Economic Journal of Emerging Markets, vol. 10, no. 1, 2005.

[6] A.I. Pujiningsih and A. Rohman, "Pengaruh Struktur Kepemilikan, Ukuran Perusahaan, Praktik Corporate Governance dan Kompensas Bonus terhadap Manajemen Laba (Studi Empiris pada Perusahaan Manufaktur yang Terdaftar di Bursa Efek Indonesia Periode 2007 2009)." Doctoral dissertation, 2011.

[7] W. Amelia and E. Hernawati, "Pengaruh Komisaris independen, ukuran perusahaan dan profitabilitas terhadap manajemen laba." Neo-Bis, vol 10, no. 1, pp. 62-77, 2016.

[8] R. Dhawan, "Firm size and productivity differential: theory and evidence from a panel of US firms." Journal of economic behavior \& organization, vol. 44, no. 3, pp. 269-293, 2001.

[9] P.E.D.M. Dewi, K.A.K. Saputra, and M.A. Prayudi, "Hubungan Kualitas Pengelolaan Aset Desa dan Pendapatan Asli Desa (Studi pada Desa-desa di Kabupaten Buleleng-Bali)," In Seminar Nasional Riset Inovatif, vol. 5, pp. 253-260, 2017.

[10] A.N.D.A. Putra and P.V. Lestari, "Pengaruh Kebijakan Dividen, Likuiditas, Profitabilitas dan Ukuran Perusahaan Terhadap Nilai Perusahaan.” E-Jurnal Manajemen Universitas Udayana, vol. 5, no. 7, 2016

[11] A.W.Y. Putra and I.B. Badjra, "Pengaruh leverage, pertumbuhan penjualan dan ukuran perusahaan terhadap profitabilitas." E-Jurnal Manajemen Universitas Udayana, vol. 4, no. 7, 2015.

[12] G. Donaldson and B. Fox, Corporate debt capacity: A study of corporate debt policy and the determination of corporate debt capacity. Beard Books, 2000

[13] S.C. Myers and N.S. Majluf, "Corporate financing and investment decisions when firms have informationthat investors do not have (No. w1396)," National Bureau of Economic Research, 1984.

[14] R.A. Brealey, S.C. Myers, and F. Allen, "Brealey, Myers, and Allen on real options." Journal of Applied Corporate Finance, vol. 20, no. 4, pp. 58-71, 2008.

[15] A.O. Scoreboard, "Financing SMEs and Entrepreneurs 2013." 2019.

[16] B. Rijkers, H. Arouri, C. Freund, and A. Nucifora, "Which firms create the most jobs in developing countries? Evidence from Tunisia," The World Bank, 2014.

[17] G. Aga, D.C. Francis, and J.R. Meza, "SMEs, age, and jobs: A review of the literature, metrics, and evidence." The World Bank, 2015.

[18] P.E. Petrakis and P.C. Kostis, "The role of knowledge and trust in SMEs". Journal of the Knowledge Economy, vol. 6, no. 1, pp. 105-124, 2015

[19] T. Lindsey, Indonesia, law and society. Federation Press, 2008.

[20] M.T. Nawawi, "Pengembangan dan Pembinaan Karier Karyawan." Buletin Ilmiah, 2004.

[21] J.S. Hasibuan and B. Silvya, "Pengaruh Disiplin Kerja dan Motivasi Terhadap Kinerja Karyawan.” In Prosiding Seminar Nasional USM, vol. 2, no. 1, pp. 134-147, 2019.

[22] S. Arthur and S.M. Sheffrin, Economics: Principles in action. Upper Saddle River, New Jersey, 7458, 173, 2003.

[23] J.K. Shim, J.G. Siegel, and N. Dauber, Corporate Controller's Handbook of Financial Management 2008-2009. Cch. 2008.

[24] J. Downes and J.E. Goodman, Dictionary of finance and investment terms. Simon and Schuster. 2014

[25] K. Case and R. Fair, Principles of Economics. Upper Saddle River, NJ: Pearson Education. 2007, p. 54.

[26] H.I. Smith, Smith's Financial Dictionary. Moody's Magazine, 1908. 
[27] N. Barr, Problems and definition of measurement. In Economics of the welfare state. New York: Oxford University Press, 2004, pp. 121-124.

[28] R. Malik and H. Siringoringo, "Analisis Pengaruh Kredit, Aset, dan Jumlah Pegawai Terhadap Pendapatan Usaha Kecil Menengah (UKM) penerima kredit Bank Perkreditan Rakyat.” Jurnal Ekonomi Universitas Gunadarma, 2007

[29] M. Imron and P.A. Wibowo, "Analisis Faktor-faktor yang Mempengaruhi Tingkat Keberhasilan USAha (Studi pada Warung?? Nasi Kucing? di Kabupaten Jepara)." Jurnal Dinamika Ekonomi dan Bisnis, vol. 5, no. 2, p. 294024, 2008.

[30] A. Handika and N.H.S. Fatimah, "Analisis Faktor-Faktor Yang Mempengaruhi Pendapatan Pedagang Kaki Lima (Studi Di Seputar Alun-Alun Kabupaten Klaten)" Doctoral dissertation, Universitas Muhammadiyah Surakarta, 2017.

[31] S.F. Nurhayati, “Analisis Kondisi Sosial Ekonomi, Kendala dan Peluang Usaha Pedagang Kaki Lima: Studi pada Pedagang Kaki Lima di Seputar Alun-Alun Kabupaten Klaten.” 2017.
[32] N.P.C.A.T. Meidiana and A.A.I.N. Marhaeni, "Pengaruh Kepemilikan Aset, Ketersediaan Infrastruktur, dan Pendidikan terhadap Pendapatan dan Kesejahteraan Rumah Tangga Miskin.” 2019.

[33] H. Jogiyanto, Teori Portofolio dan Analisis Investasi (Edisi Kesepuluh) Yogyakarta: BPFE-Yogyakarta, 2015.

[34] R.H. Usman, "Faktor-Faktor Yang Berpengaruh Terhadap Pendapatan Pengrajin Sngkok di Kecamatan Gresik Kabupaten Gresik.” Doctoral dissertation, Universitas Muhammadiyah Gresik, 2016.

[35] D.M.A. Artaman, N.N. Yuliarmi, and I.K. Djayastra, "Analisis faktorfaktor yang mempengaruhi pendapatan pedagang pasar seni sukawati gianyar.” E-Jurnal Ekonomi dan Bisnis Universitas Udayana, vol. 4, no. 02, pp. 87-105, 2015.

[36] A.N. Priyandika and N. Woyanti, "Analisis Pengaruh Jarak, Lama Usaha, Modal, Dan Jam Kerja Terhadap Pendapatan Pedagang Kaki Limakonveksi (Studi Kasus Di Kelurahan Purwodinatan Kota Semarang)" Doctoral dissertation, Fakultas Ekonomika dan Bisnis, 2015 